\title{
Effect of Pre-Sowing Treatments on Seed Germination and Initial Seedling Growth Performance of Canarium resiniferum: A Native Threatened Tree of Bangladesh
}

\author{
G.N.T. Hasnat ${ }^{1 *}$, M.K. Hossain ${ }^{2}$, M.K. Bhuiyan ${ }^{2}$, M.S. Alam² and M.A. Hossain ${ }^{2}$ \\ ${ }^{1}$ Climate Resilient Ecosystem and Livelihood Project of USAID, \\ Community Development Centre, Bangladesh \\ ${ }^{2}$ Institute of Forestry and Environmental Sciences, Chittagong University, Bangladesh
}

Date Received: 11-11-2015_ Date Accepted: 05-01-2016

\begin{abstract}
Canarium resiniferum is an economically and aesthetically important native threatened tree species of Bangladesh. In natural condition 78.5-98.7\% seeds do not germinate due to seed predation. This study was conducted at the Seed Research Laboratory and Nursery of Institute of Forestry and Environmental Sciences of Chittagong University, Bangladesh in 2013 to find out appropriate pre-sowing treatment for maximising germination and initial seedling growth. Eleven pre-sowing treatments were used for both the seeds sown in polybags and seeds sown in propagator house. Results revealed that germination started at first (after 20 days of seed sown) in seeds immersed in cold water for 24 hours and germination completed within 38 days. Significantly higher $(\mathrm{p}<0.05)$ germination percentage $(33 \%)$, germination energy $(16.7 \%)$, plant percent $(33 \%)$ and germination value (0.4) were found with the seeds immersed in cold water for 24 hours. Seedling height measured at three, four and five ${ }^{l}$ months after the seed germination in case of seeds treated by immersion in cold water for 24 hours was also greater than others. Therefore, pre-sowing treatment by immersion in cold water for 24 hours was more effective in germination and production of quality vigor seedling of $\mathrm{C}$. resiniferum.
\end{abstract}

Keywords: Canarium resiniferum, Pre-sowing treatment, Seed, Germination, Seedling growth

\section{Introduction}

Canarium resiniferum Brace ex King (Family-Burseraceae), locally known as Dhup, is a native threatened tree species of Bangladesh (Khan et al., 2001). It is a lofty, evergreen tree with tall cylindrical bole, and the trunk is often buttressed. The plant naturally grows in moist semievergreen forests of Chittagong, Chittagong Hill Tracts, Cox's Bazar, Rangamati and Sylhet districts in Bangladesh (Das and Alam, 2001). Its fruit is a drupe, about 3.4-5.0 cm long and 1.5-2.8 $\mathrm{cm}$ wide and 60-85 fruits are weighed per 1 kilogram. Seeds are pointed at both ends, about 3-4.8 $\mathrm{cm}$ long, 1-2 cm wide, trigonous, bony and 3-celled but usually containing single embryo. A total of 190-345 seeds weigh $1 \mathrm{~kg}$. Generally, 1-2\% seeds found with double embryo. Flowering and Fruiting time varied from June to December. C. resiniferum is an economically and aesthetically important tree species (Johnsingh, 2006). It produces non-timber forest product (NTFP) where

Correspondence: gnthasnat@gmail.com

Tel: +881783736689

ISSN 2235-9370 Print/ISSN 2235-9362 Online (C) University of Sri Jayewardenepura 
resins are collected (GEF, 2009) from mature plants (Rathor and Rathor, 2013). The plant is also used locally for medicine, to make wax, varnish, incense, turpentine, producing veneer and plywood. Fruits are also eaten by the birds (Molur, 2001). Conservation status of C. resiniferum is data deficient and it needs field survey to assess and determine appropriate conservation program (Khan et al., 2001).

The main threat for the reproduction of this species is that $78.5-98.7 \%$ seeds do not regenerate due to seed predation in Natural condition (Velho et al., 2012). However, no cultivated stocks are available for reforestation or enrichment plantation and no propagation techniques are recommended yet for germination improvement (Molur, 2001). In order to improve germination percentage and to save this economically valuable plant species from becoming extinct, nursery techniques with appropriate pre-sowing treatments is the only way (Alamgir and Hossain, 2005). There are some researchers conducted by Hossain (1995), Ali et al. (1997) and Haider (2014), on pre-treatment effects of several plantation species in Bangladesh. However, no researches about pre-sowing effects on germination and initial seedling growth of $C$. resiniferum conducted yet. Therefore the main purpose of this study was to find out the appropriate pre-sowing treatments that maximize total germination and produce more vigour seedlings.

\section{Materials and Methods}

\subsection{Study site, seed collection, handling, and growing media}

The experiment was conducted in a propagator house and nursery located within the Seed Research Laboratory of the Institute of Forestry and Environmental Sciences, University of Chittagong (IFESCU), Bangladesh. Fruits of $C$. resiniferum were collected from Adampur at Moulavi Bazar district of Bangladesh in October, 2012. Seeds were extracted manually before sowing by depulping mature fruits in order to enhance germination. Brownish seeds were then dried for four days in open sun in order to reduce the moisture. Only healthy seeds were sown in polybags $(15 \times 10 \mathrm{~cm})$ and propagator house for experiment. The media of the polybags was mixture of topsoil collected from forest floor and cow dung in the ratio of 3:1. The media used in propagator house was fine Sylhet sand.

\subsection{Experimental design and treatment combination}

Eleven pre-sowing treatments with three replications for each were set in the experiment. For justification of seed germination behaviour and seedling growth performances of the treated seeds, a sample plot was designed with non-treated seeds as a control. A completely randomised design was used for this experiment. The pre-treatment methods were as follows:

$\mathrm{T}_{0}$ : Seeds with no treatment and sown in poly bag only (Control)

$\mathrm{T}_{1}$ : Whole fruits without any treatment sown in poly bag

$\mathrm{T}_{2}$ : Seeds treated with sand paper at distal end of the seed

$\mathrm{T}_{3}$ : Seeds treated with nicking/nail clipping at distal end of the seed

$\mathrm{T}_{4}$ : Seeds immersed in cold water for 24 hours

$\mathrm{T}_{5}$ : Seeds immersed in hot water for 1 minute 
$\mathrm{T}_{6}$ : Seeds immersed in $10 \%$ concentrated $\mathrm{H}_{2} \mathrm{SO} 4$ for 3 minutes

$\mathrm{T}_{7}$ : Seeds immersed in $10 \%$ concentrated $\mathrm{H}_{2} \mathrm{SO} 4$ for 5 minutes

$\mathrm{T}_{8}$ : Seeds immersed in $10 \%$ concentrated $\mathrm{HCl}$ for 3 minutes

$\mathrm{T}_{9}:$ Seeds immersed in $10 \%$ concentrated $\mathrm{HCl}$ for 5 minutes

$\mathrm{T}_{10}$ : Seeds sown in propagator house (fine sand)

\subsection{Pre-sowing treatment procedure}

For each treatment, 30 healthy seeds were selected randomly and then provided with the treatments through following procedures. i) Sand paper treatment: Seeds were manually rubbed with sand paper at the distal end. ii) Nail clipping: Seed were mechanically nicked at the distal end. iii) Cold water treatment: Seeds were put in a beaker and soaked for 24 hours with cold water at room temperature. iv) Hot water treatment: Seeds were put in a beaker and soaked into boiled water for 1 minute. v) Acid treatment: Seeds were put into four separate beakers then $10 \%$ concentrated $\mathrm{H}_{2} \mathrm{SO} 4$ was added in 2 beakers and $10 \%$ concentrated $\mathrm{HCl}$ was added in remaining 2 beakers. Two beakers one with $\mathrm{H}_{2} \mathrm{SO} 4$ and another with $\mathrm{HCl}$ were left 3 minutes. The remaining two beakers are left for 5 minutes. After immersion, the solution was drained off and repeatedly rinsed in running water tap.

\subsection{Seed germination behaviour measurement}

The germination behaviour was recorded daily by counting of germinated seeds from the date of seed sown to the end of seed germination. Germination percentage and cumulative germination percentage were calculated following the work of Kumar, 1999. When the mean daily germination reached to its peak, the germination percentages was also determined to find out the germination energy (Dwivedi, 1993). Seedlings survived at the end of the experiment were counted to determine survival percent. Germination value was found by multiplying peak value of germination (PV) and mean daily germination (MDG).

\subsection{Seedling vigour measurement}

At the end of three months of seed germination, three vigour seedlings from each replication were selected for measuring seedling height. Height measurement was continued up to five months of seed germination. Shoot height was measured from collar region to the tip of seedling.

\subsection{Statistical analysis}

Data were statistically analysed by using SPSS $\odot$ and data were subjected to analysis of variance and Duncan's Multiple Range Test (DMRT).

\section{Results}

\subsection{Germination period}

Germination behaviour of $C$. resiniferum seeds was significantly affected by immersion in cold water, hot water, chemical scarification and manual scarification. Germination was started earlier (at 20 days) in seeds treated by immersion in cold water for 24 hours whereas seeds sown in 
propagator house took 56 days for initiation of germination (Table 1). Germination of seeds continued upto 38 days in $\mathrm{T}_{4}$ (seeds soaked in cold water for 24 hours) but it took 64 days to complete germination in $\mathrm{T}_{10}$ (seeds sown in fine sand of propagator house). Chemical scarification had almost no impact on the period of germination initiation as it was comparable to that of control (27 days). Therefore, it is clear that immersion in cold water for 24 reduced the seed dormancy period.

Table 1: Germination parameters of Dhup (C. resiniferum) seeds under different pre-sowing treatments.

\begin{tabular}{|c|c|c|c|c|c|c|}
\hline Treatments & $\begin{array}{l}\text { ermination } \\
\text { start (day) }\end{array}$ & $\begin{array}{l}\text { Germinatio } \\
\mathrm{n} \text { end (day) }\end{array}$ & $\begin{array}{c}\text { Germination } \\
\text { percentage }(\%)\end{array}$ & $\begin{array}{c}\text { Germination } \\
\text { energy }(\%)\end{array}$ & $\begin{array}{c}\text { Plant } \\
\text { percent }(\%)\end{array}$ & $\begin{array}{l}\text { Germinati } \\
\text { on value }\end{array}$ \\
\hline $\mathrm{T}_{0}$ (Seed only) & 27 & 39 & $20^{\mathrm{abc} *}$ & $10^{\mathrm{abc}}$ & $20^{\mathrm{abc}}$ & $0.2^{\mathrm{a}}$ \\
\hline $\mathrm{T}_{1}$ (Whole fruit) & _ & - & - & - & - & . \\
\hline $\mathrm{T}_{2}$ (Sand paper) & 27 & 34 & $17^{\mathrm{abc}}$ & $10^{\mathrm{abc}}$ & $17^{\mathrm{abc}}$ & $0.1^{\mathrm{a}}$ \\
\hline $\mathrm{T}_{3}$ (Nicking) & 26 & 30 & $20^{\mathrm{abc}}$ & $13.3^{\mathrm{bc}}$ & $20^{\mathrm{abc}}$ & $0.2^{\mathrm{a}}$ \\
\hline $\mathrm{T}_{4}$ (Cold water, $24 \mathrm{hr}$.) & 20 & 38 & $33^{\mathrm{c}}$ & $16.7^{\mathrm{c}}$ & $33^{\mathrm{c}}$ & $0.4^{\mathrm{a}}$ \\
\hline $\mathrm{T}_{5}$ (Hot water, 1 min.) & 43 & 43 & $3^{\mathrm{ab}}$ & $3.3^{\mathrm{ab}}$ & $3^{\mathrm{ab}}$ & $0.01^{\mathrm{a}}$ \\
\hline $\mathrm{T}_{6}\left(\mathrm{H}_{2} \mathrm{SO}_{4}, 3\right.$ min. $)$ & 27 & 39 & $33^{\mathrm{c}}$ & $16.7^{\mathrm{c}}$ & $33^{c}$ & $0.3^{\mathrm{a}}$ \\
\hline $\mathrm{T}_{7}\left(\mathrm{H}_{2} \mathrm{SO}_{4}, 5\right.$ min. $)$ & 29 & 50 & $17^{\mathrm{abc}}$ & $10^{\mathrm{abc}}$ & $17^{\mathrm{abc}}$ & $0.1^{\mathrm{a}}$ \\
\hline $\mathrm{T}_{8}(\mathrm{HCl}, 3 \mathrm{~min})$. & 27 & 35 & $30^{\mathrm{bc}}$ & $16.7^{\mathrm{c}}$ & $30^{\mathrm{bc}}$ & $0.3^{\mathrm{a}}$ \\
\hline $\mathrm{T}_{9}(\mathrm{HCl}, 5 \mathrm{~min})$. & 24 & 34 & $27^{\mathrm{abc}}$ & $10^{\mathrm{abc}}$ & $27^{\mathrm{abc}}$ & $0.4^{\mathrm{a}}$ \\
\hline $\begin{array}{l}\mathrm{T}_{10} \text { (Seed in propagator } \\
\text { house) }\end{array}$ & 56 & 64 & $10^{\mathrm{abc}}$ & $10^{\mathrm{abc}}$ & $10^{\mathrm{abc}}$ & $0.02^{\mathrm{a}}$ \\
\hline
\end{tabular}

(*) Means followed by the same letter(s) in the same column are not significantly different at $\mathrm{P}<0.05$, Duncun's Multiple Range Test (DMRT).

\subsection{Germination percentage}

Germination percentage of $C$. resiniferum varied significantly with the treatments. According to the results significantly highest (33\%) germination percentage was observed in $\mathrm{T}_{4}$ (cold water immersion of seeds for 24 hours) and $\mathrm{T}_{6}$ (seeds immersed in $10 \%$ concentrated $\mathrm{H}_{2} \mathrm{SO}_{4}$ for 3 minutes) followed by $30 \%$ in $\mathrm{T}_{8}$ (immersed in $10 \%$ concentrated $\mathrm{HCl}$ for 3 minutes) and $27 \%$ in $\mathrm{T}_{9}$ (immersed in $10 \%$ concentrated $\mathrm{HCl}$ for 5 minutes) (Table 1). Germination percentage was least $(3 \%)$ in $\mathrm{T}_{5}$ (seeds immersed in hot water for 1 minute) and no germination $(0 \%)$ found in $\mathrm{T}_{1}$ (whole fruits without any treatment sown in polybag).

\subsection{Germination energy}

Germination energy was calculated to explore the speed of germination under different presowing germination. It varied from $3.3 \%$ to $16.7 \%$ among the treatments. The highest germination energy $(16.7 \%)$ was calculated for $\mathrm{T}_{4}, \mathrm{~T}_{6}$ and $\mathrm{T}_{8}$ followed by $\mathrm{T}_{3}(13.3 \%)$. Germination energy also showed that only $10 \%$ of seeds were germinated by peak germination day in seeds treated with sand paper at distal end $\left(\mathrm{T}_{2}\right)$, immersed in $10 \%$ concentrated $\mathrm{H}_{2} \mathrm{SO}_{4}$ for 5 minutes $\left(\mathrm{T}_{7}\right)$, sown in propagator house $\left(\mathrm{T}_{10}\right)$ and control.

Germination value is closely related to survival of seedlings in the field conditions. However in this experiment, germination values found for different treatments were lower and not significant. Seeds soaked in cold water for 24 hours and seeds immersed in $10 \%$ concentrated $\mathrm{HCl}$ for 5 
minutes showed the maximum germination value (0.4) (Table 1). On the other hand, seeds immersed in hot water for 1 minute showed minimum (0.01) germination value.

\subsection{Pattern of germination}

Daily germination percentages were summed to obtain cumulative germination percentage for each pre-sowing treatment on each assessment date. Cumulative germination percentage varied with the treatments. Germination in $\mathrm{T}_{4}$ started after 20 days of seed sown, rose slowly and continued germinated up to $33 \%$ within 38 days. In $\mathrm{T}_{3}$ and $\mathrm{T}_{8}$ germination rose sharply from day 26 and reached its highest on day 35 and remained constant up to the end of the germination (Figure 1).

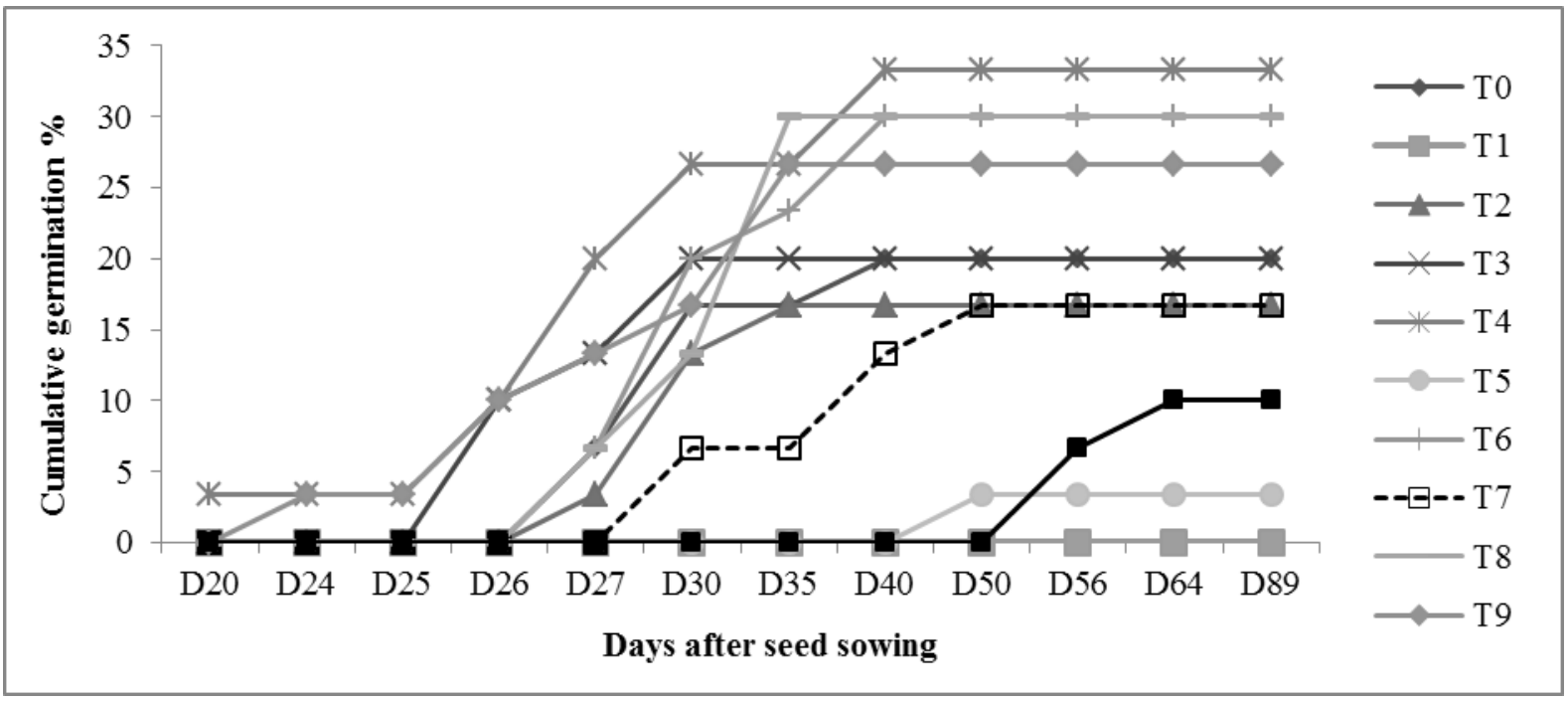

Figure 1: Mean cumulative germination percent of Dhup (C. resiniferum) under different presowing treatments $\left[\right.$ Here, $\mathrm{T}_{0}=$ seed only, $\mathrm{T}_{1}=$ Whole fruit, $\mathrm{T}_{2}=$ Sand paper, $\mathrm{T}_{3}=$ Nicking, $\mathrm{T}_{4}=$ Cold water $(24 \mathrm{hr}) . \mathrm{T}_{5}=$ Hot water $(1 \mathrm{~min}), \mathrm{T}_{6}=$ soaked in $\mathrm{H}_{2} \mathrm{SO}_{4}(3 \mathrm{~min}), \mathrm{T}_{7}=$ soaked in $\mathrm{H}_{2} \mathrm{SO}_{4} 5 \mathrm{~min}$, $\mathrm{T}_{8}=$ soaked in $\operatorname{HCL}(3 \mathrm{~min}), \mathrm{T}_{9}=$ soaked in $\operatorname{HCL}(5 \mathrm{~min})$ and $\mathrm{T}_{10}=$ seed in propagator house $]$

\subsection{Shoot growth}

Seeds soaked in cold water for 24 hours produced vigour and straight seedlings with shoot height of 9.8, 13.0 and $26.7 \mathrm{~cm}$ at the end of 3,4 and 5 months respectively (Figure 2). The growth parameter (shoot height) was also affected by $\mathrm{T}_{6}$ as it produced shoot of $20.2 \mathrm{~cm}$ height followed by $\mathrm{T}_{3}(17.6 \mathrm{~cm})$ which were significantly higher than control $(12.1 \mathrm{~cm})$. The shoot length found in $\mathrm{T}_{2}$ $(10.9 \mathrm{~cm})$ and $\mathrm{T}_{10}(6.8 \mathrm{~cm})$ were lower than that is of control $(12.1 \mathrm{~cm})$. Hossain et al. (2005) also showed that pre-sowing treatments have significant impact on initial seedling growth i.e. shoot length. 


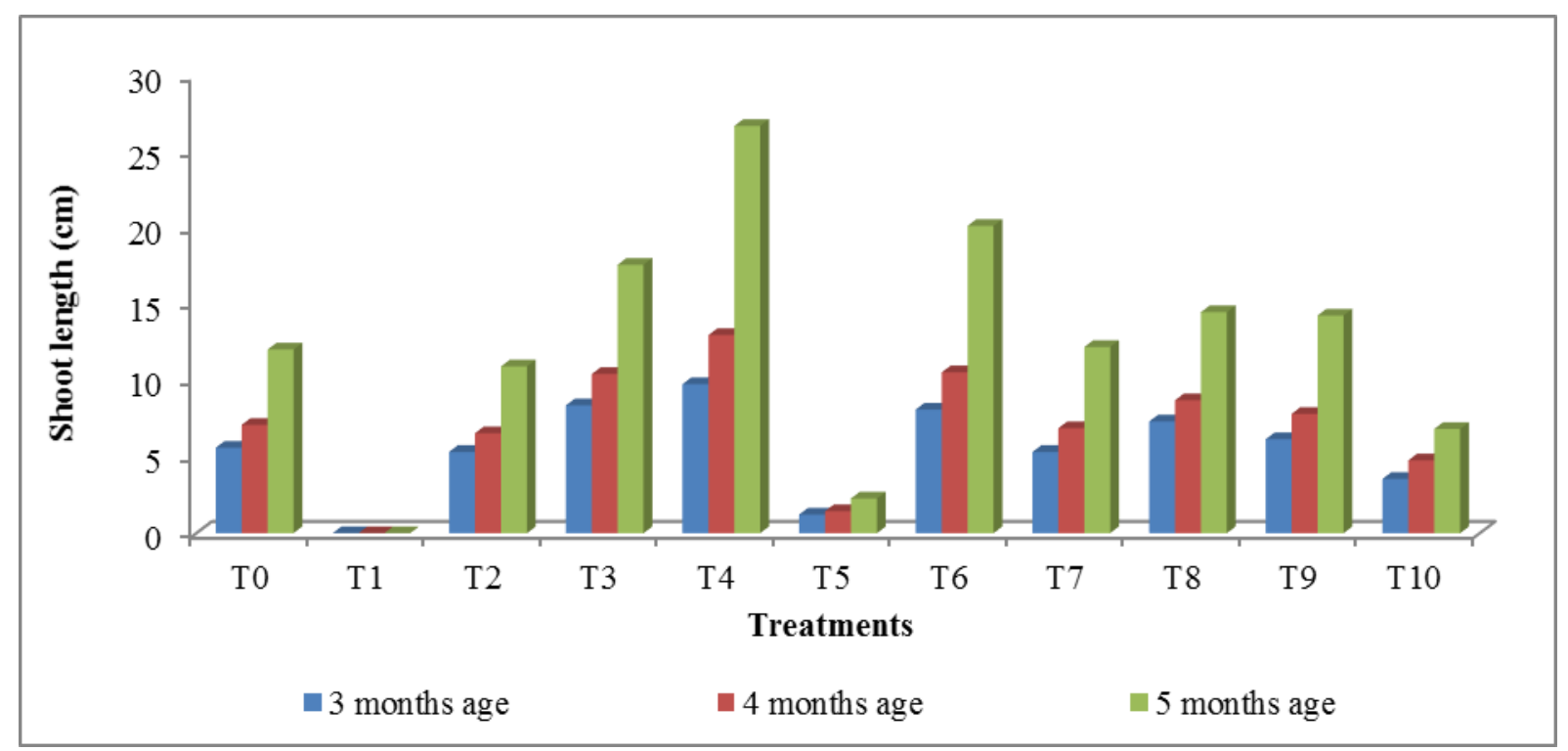

Figure 2: C. resiniferum shoot growth under different treatments

\section{Discussion}

Effective pre-sowing treatments like sand abrading and leaching by water can influence seed germination of hard coated seeds (Brown, 1972; Villiers, 1972; Bewley and Black, 1982; Doran et al., 1983; Napier, 1987; Palani et al., 1995; Schmidt, 2000; Hossain et al., 2005; Anand et al., 2012; Haider et al., 2014). Seeds of Terminalia chebula showed better germination when were soaked in cold water for 48 hours (Hossain et al., 2005). In that study seeds of Terminalia chebula which were morphologically similar to $C$. resiniferum started germination in 29 days and continued upto 86 . Findings of the present study showed that $C$. resiniferum seeds soaked in cold water for 24 hours germinated earlier (in 20 days) and provided highest germination (33\%) which supports the finding of Bebawi and Mohamed (1985), Some et al. (1989) and Hossain et al. (2005) who reported highest germination rate of some tropical hard coated seeds by soaking in cold water for 24 hours. Hossain et al. (2005) reported highest germination percentage $(66.7 \%)$ for $T$. chebula when fruit were depulped and soaked in cold water for 48 hours and lowest germination (48.0\%) in control. Azad et al. (2011) estimated 52\% germination of Acacia auriculiformis seeds in cold water treatment.

In the present study, seeds of $C$. resiniferum sown with pulp showed no germination at all $(0 \%)$ while de-pulped seeds provided $33 \%$ germination. The result supports the findings of Schaefer (1989) who found seeds of some tropical and sub-tropical species completely failed to germinate without extraction from their fleshy fruit pulp. Heat damage occurred in C. resiniferum and germination rate was found only 3\% which supports the reports of Schmidt (2000) that seeds with heat sensitive embryos may be killed by boiling water treatment.

C. resiniferum immersed in $10 \%$ concentrated $\mathrm{H}_{2} \mathrm{SO}_{4}$ for 3 minutes provided highest germination percentage (33\%) which supports the findings that a concentration of $0>70 \%$ improve germination of hard coated seeds reported by Laurent and Chamshama (1987). Kumar (1999) and Schmidt (2000) mentioned that pre-sowing treatments with abrasion to sand paper, nail clipping, acid may result in non-uniform seed germination behaviour and may produce heterogeneity in 
seedlings which may lead to varying in vigour and size of the seedlings which was also observed in the present study.

Moreover, germination energy, germination vale and initial growth performance found in this research were also in line with the findings of Hossain et al. (2005) who reported enhancement of germination energy and germination value of $T$. chebula seeds soaked in cold water for 48 hours. However, the results showed that cold water soaking for 24 hours is the most effective pre-sowing treatment for germination of $C$. resiniferum seeds.

\section{Conclusion}

Pre-sowing treatments may be useful for producing maximum number of quality seedlings with minimum cost, time and labour. Since the seed coat of $C$. resiniferum is hard and attacked by insect pests it results in poor regeneration in the natural condition as well as in the nursery. Though resulted germination percentage is lower in case of $C$. resiniferum the present study with pre-sowing treatments would prove itself potential in the practical fields. Among the treatments, of seeds soaking in cold water for 24 hours was found more effective in respect to faster germination, higher germination percentage and seedling growth of $C$. resiniferum in comparison to control and other treatments. Population of the species is greatly reduced in both the natural environment and homesteads; hence it needs immediate and effective conservation initiatives. Since, the seed treatment soaking in cold water for 24 hours is easily applicable and cost effective; the treatment may be recommended for large-scale seedling production in the nurseries to go for further conservation initiatives through plantation establishment.

\section{Acknowledgement}

Authors thank Arannayk Foundation for assistance during the study. The authors gratefully acknowledge the supports of the staff of the Seed Research Laboratory and nursery of Institute of Forestry and Environmental Sciences Chittagong University.

\section{References}

Alamgir, M. and Hossain, M.K., 2005. Effect of pre-sowing treatments on Albizia procera (Roxb.) Benth seeds and initial development of seedlings in the nursery. Journal of Forestry and Environment, 3: 53-60.

Ali, M., Akhter, S., Kamaluddin, M., 1997. Study on the bearing of water treatment on seed germination and seedling growth study of Albizia procera. Indian Forester, 123(8): 764768.

Anand, B., Devagiri, G.M., Gurav, M., Vasudev, H.S., Khaple, A.K., 2012. Effects of pre-sowing seed treatments on germination and seedling growth performance of Melia dubia CAV: An important multipurpose tree. International Journal of Life Sciences, 1(3): 59-63.

Azad, S., Manik, M.R., Hasan, S., Matin, A. 2011. Effect of different pre-sowing treatments on seed germination percentage and growth performance of Acacia auriculiformis. Journal of Forestry Research, 22(2): 183-188. Available at: link.springer.com/article/10.1007 $\% 2 F s 116760110147 \mathrm{y}$

Bebawi, F.F., Mohamed, S.M., 1985. The pretreatment of seeds of six Sudanese Acacias to improve their germination response. Seed Science \& Technology, 13: 111-119.

Bewley, J.D., Black, M., 1982. Physiology and biochemistry of seeds in relation to germination, viability, dormancy and environmental control. Springer-Verlag, Berlin, pp.1-375. 
Brown, R., 1972. Germination In Steward, F.C. (ed) Plant Physiology - A Treatise. Academic Press, New York, pp.3-48.

Das, D.K., Alam, M.K., 2001. Trees of Bangladesh. Bangladesh Forest Research Institute, Chittagong, pp.1-342.

Doran, J.C., Turnbull, J.W., Boland, D.J., Gunn, B.V., 1983. Handbook on seeds of dry-zone Acacias: A guide for collecting, extracting, cleaning and storing the seed and for treatment to promote germination of dry-zone Acacias. Division of forest research, CSIRO, Australia.

Dwivedi, A.P., 1993. A text book of silviculture. International book distributors, 9/3 Rajpur Road, Dehradun - 248001, India, pp.1-505.

GEF (Global Environment Facility), 2009. Request for CEO endorsement/approval. Washington DC 20433, USA.

Haider, M.R., Alam, M.S., Hossain, M.A. 2014. Effect of pre-sowing treatment on seed germination and seedling growth attributes of Acacia catechu Wild in nursery and field conditions. International Journal of Latest Research in Science and Technology, 3(4):214-219. Available at: http://www.mnkjournals.com/ijlrst_files/Page752.htm.

Hossain, M.K., 1995. Growth and development of Dalbergia sissoo seedlings growth under different combinations of potting media. Chittagong University Studies, Part II: Science, 19(2): 259-264.

Hossain, M.A., Arefin, M.K., Khan, B.M., Rahman, M.A. 2005. Effects of seed treatments on germination and seedling growth attributes of Horitaki (Terminalia chebula Retz.) in the nursery. Research Journal of Agriculture and Biological Sciences 1(2): 135-141.

Johnsingh, A.J.T., 2006. Field Days: A naturalist's journey through South and Southeast Asia. Universities Press (India) Private Limited, 3-5-819, Hyderguda, Hyderabad, India, 1-305.

Khan, M.S., Rahman, M.M., Ali, M.A. (eds), 2001. Red data book of vascular plants of Bangladesh. Bangladesh national herbarium, Binimoy Printers, 37/2 Purana Paltan, Dhaka1000.

Kumar, V., 1999. Nursery and plantation practices in forestry. Scientific Publishers, 5A, New Pali Road, Jodhpur - 342001. pp.65-159.

Laurent, N., Chamshama, S.A.O., 1987. Studies on the germination of Erythrina abyssinica and Juniperus procera. The International Tree Crops Journal, 4: 291-298.

Molur, S., Priya, A.R.B., Walker, S., (eds.) 2001. Non timber forest products of Nilgiri Biosphere Reserve, Report of conservation assessment and management plan workshop, The Indian Institute of Forest Management, Nehru Nagar, Bhopal, Madhya Pradesh 462003, pp.1-107.

Napier, I., 1987. Pre-germination treatment of Cassia siamea and Leucaena leucocephala seeds. Banko Janakari, 1: 5-6.

Palani, M, Dasrhagir, M. G., Kumaran, K., 1995. Effect of pre-sowing chemical treatment on germination and seedling growth in Acacia nilotica. International Tree Crops Journal, 8: 189-192.

Rathor, B.S., Rathor, V.S., 2013. Management of natural resource for sustainable development. Daya Publishing House, A Division of Astral International Private Limited, 81, Darya Ganj, Near Hindi Park, Delhi Medical Association Road, New Delhi-110 002.

Schaefer, C., 1989. Seed testing research on species indigenous to Kenya In Tropical tree seed research. Proceedings of an International Workshop held at the Forestry Training Centre, Gympie, Qld, Australia, 28: 132-139. 
Schmidt, L., 2000. Guide to handling tropical and subtropical forest seed. Danida forest seed center, Krogerupvej 21, Humleback, Denmark, pp.1-510.

Some, L.M., Gamene, C.S., Verwey, H., 1989. A study of the causes of poor germination of Anogeissus leiocarpus seeds In Tropical tree seed research. Proceedings of an International Workshop held at the Forestry Training Centre. Gympie, Qld, Australia, 28: 37-40.

Velho, N., Isvaran, K.,Datta, A., 2012. Rodent seed predation: effects on seed survival, recruitment, abundance, and dispersion of bird-dispersed tropical trees. Oecologia, 169 (4): 995-1004.

Villiers, T.A., 1972. Seed dormancy In Seed Biology. Academic Press New York, 2:220-281. 